\title{
Segmentasi Perkebunan Kelapa Sawit dengan Data Mining Teknik K-Means Clustering Berdasarkan Luas Areal, Produksi dan Produktivitas
}

\author{
Trisna Yuniarti ${ }^{1}$, Dahliyah Hayati ${ }^{1}$ \\ ${ }^{I}$ Politeknik APP Jakarta, Jalan Timbul No.34, Jakarta Selatan, 12630, Indonesia
}

\section{ARTICLE INFORMATION}

Received: October 22, 2021

Revised: December 24, 2021

Available online: December 31, 2021

\section{KEYWORDS}

Centroid, Clustering, Data Mining, K-Means, Oil Palm

\section{CORRESPONDENCE}

Name: Trisna Yuniarti

E-mail: trisna.yuniarti@poltekapp.ac.id

\begin{abstract}
A B S T T R A C $\mathbf{T}$
The oil palm is the most productive plantation product in Indonesia. Government strategies and policies related to oil palm plantations continue to be carried out considering that the plantation area is increasing every year. Segmentation of oil palm plantations based on area, production, and productivity aims to identify groups of potential oil palm plantations in the territory of Indonesia. This segmentation can provide consideration in formulating strategies and policies that will be made by the government. The segmentation method for grouping oil palm plantations uses the K-Means Clustering Data Mining technique with 3 clusters specified. Data mining stages start from data collection until representation is carried out, where 34 data sets are collected, only 25 data sets can be processed further. The results of this grouping obtained three plantation segments, namely $72 \%$ of the plantation group with low potential, $20 \%$ of the plantation group with medium potential, and $8 \%$ of the plantation group with high potential.
\end{abstract}

\section{PENDAHULUAN}

Indonesia merupakan negara agraris yang banyak menghasilkan komoditas perkebunan. Hasil komoditas tersebut memiliki kontribusi yang sangat tinggi bagi perekonomian negara. Salah satu barang dagangan ekspor yang bernilai tinggi dihasilkan dari perkebunan kelapa sawit. Berdasarkan status pengusahaan, jenis perkebunan kelapa sawit dilakukan oleh Perkebunan Besar Negara (PBN), Perkebunan Besar Swasta (PBS), dan Perkebunan Rakyat (PR). Perkebunan tersebut hampir banyak ditemukan di Indonesia, terutama di Pulau Sumatera dan Kalimantan. Produk yang dihasilkan dari perkebunan kelapa sawit berupa minyak kelapa sawit atau sering disebut CPO dan minyak inti kelapa sawit atau sering disebut PKO. Produk tersebut dapat diolah kembali untuk keperluan beberapa industri makanan maupun non makanan, bahkan sebagai sumber energi terbarukan [1].

Berdasarkan hasil studi literatur diketahui bahwa dari beberapa periode lahan dan produksi kelapa sawit mengalami perkembangan yang signifikan. Kegiatan pengembangan perkebunan kelapa sawit memiliki pengaruh bagi perekonomian masyarakat, yaitu terciptanya lapangan kerja dan lapangan kerja bagi masyarakat setempat. Selain berdampak positif, perluasan perkebunan ini juga memiliki dampak negatif, yaitu adanya perluasan dan pengusahaan perkebunan tanpa legalitas yang pada akhirnya merusak keanekaragaman ekosistem serta menyebabkan deforestasi [2]. Berdasarkan data lima tahun Direktorat Jenderal Perkebunan, yaitu tahun 2014 sampai dengan 2018, luas areal meningkat dengan rata-rata pertumbuhan sebesar 7,89\%. Areal perkebunan diprediksi akan terus naik seiring dengan perkembangan industri dan pemenuhan minyak nabati di dunia. Gambar 1 . memperlihatkan produktivitas perkebunan kelapa sawit mengalami kenaikan rata-rata sebesar $0,37 \%$ dari tahun 2014 sampai dengan tahun 2020 [3]. Produktivitas tersebut diperlihatkan dari hasil PBN, PBS, dan PR. Indonesia merupakan negara pengekspor minyak kelapa sawit tertinggi ke berbagai negara di dunia. Pada saat ini, pemerintah berusaha untuk meningkatkan produktivitas kelapa sawit guna memenuhi permintaan pelanggan dari dalam negeri maupun luar negeri. Adanya peningkatan 
produktivitas diharapkan dapat meningkatkan pendapatan para petani.

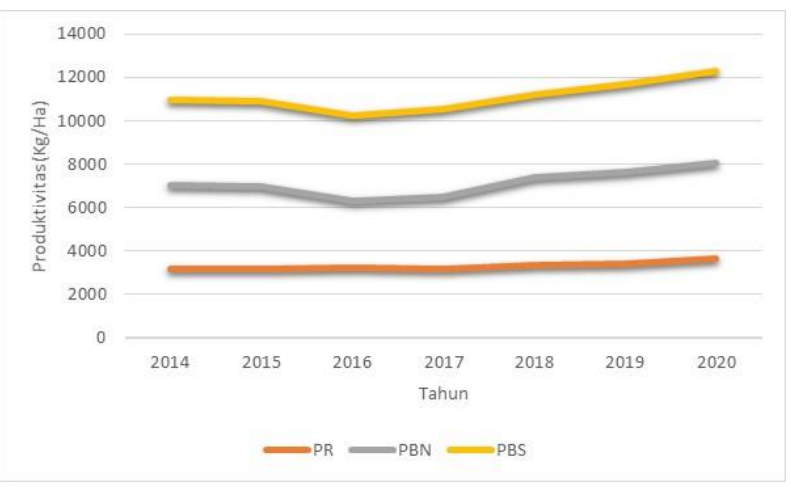

Gambar 1. Produktivitas Kelapa Sawit Indonesia pada Tahun $2014-2020$

Indonesia menjadi negara tujuan pengimpor kelapa sawit ke beberapa negara di dunia. Guna menyeimbangkan supply dan demand hasil produk kelapa sawit tersebut, pemerintah melakukan kajian proyeksi kebutuhan hasil perkebunan kelapa sawit untuk beberapa tahun ke depan. Dengan demikian, dapat dilakukan prediksi ketersediaannya tanpa mengabaikan faktor lingkungan sebagai dampak lain dari hasil pengolahan produksi kelapa sawit, walau secara ekonomi akan memberikan manfaat [4]. Pengembangan berupa perluasan diiringi dengan peningkatan produktivitas harus dilakukan secara bertanggung jawab. Oleh karena itu, Kementerian Pertanian menetapkan suatu pedoman Perkebunan Kelapa Sawit Berkelanjutan Indonesia atau Indonesian Sustainable Palm Oil (ISPO) guna setiap perusahaan perkebunan sawit mematuhi perundang-undangan yang tercantum pada pedoman tersebut.

Hampir seluruh wilayah di Indonesia terdapat perkebunan kelapa sawit, akan tetapi belum diketahui secara pasti besarnya potensi perkebunan tersebut dilihat dari segi produktivitas, luas areal dan jumlah produksi yang dimiliki pada masing-masing propinsi. Metode yang dapat digunakan untuk mengetahui potensi perkebunan kelapa sawit yang memiliki karakteristik yang sama berdasarkan luas areal, jumlah produksi, dan produktivitas adalah dengan menggunakan Data Mining teknik K-Means Clustering. Beberapa penelitian yang menggunakan metode ini telah dilakukan untuk pengelompokkan data penjualan $[5,6,7,8]$. Penelitian lainnya menggunakan metode ini untuk melakukan pengelompokkan distribusi suatu produk $[9,10]$. Selain itu, teknik K-Means Clustering dapat juga dikombinasikan dengan metode lainnya, seperti pada penelitian dalam memprediksi profil pemakaian beban panas skala besar di sektor komersial, industri, publik atau residensial yang fokus pada industri manufaktur [11]. Pada penggunaan teknik yang sama, penelitian pengelompokan yang memfokuskan pada tanaman kelapa sawit dilakukan untuk pemetaan hasil produksi buah sawit, mengetahui blok tanaman kelapa sawit paling produktif dan tidak produktif, serta untuk mengetahui pengelompokan jenis tanaman kelapa sawit produktif sehingga dapat meningkatkan produksi dan kesejahteraan karyawan [12, 13, 14].

Clustering merupakan salah satu teknik untuk melakukan pengelompokkan data dengan membagi data sesuai dengan kelompok objek yang sama, dimana objek tersebut memiliki kemiripan satu sama lain [15]. Adanya perkembangan teknologi dan internet memberikan kemudahan akses dalam pengumpulan data. Data tersebut dapat dimanfaatkan lebih dalam untuk memperoleh pengetahuan atau informasi yang baru bagi penggunanya. Pada data mining, teknik clustering yang sering digunakan adalah K-Means, yaitu algoritma pengelompokkan yang berdasarkan pada kesamaan antara objek data statis, sederhana diimplementasikan, serta memiliki kompleksitas waktu linier yang rendah [16].

Penelitian ini bertujuan untuk melakukan pengelompokkan perkebunan kelapa sawit di Indonesia berdasarkan data luas areal, produksi, dan produktivitas. Adanya pengelompokkan ini diharapkan akan diketahui informasi lebih dalam dan dapat digunakan untuk membuat kebijakan atau strategi dalam peningkatan perkebunan kelapa sawit berkelanjutan di seluruh wilayah Indonesia. Pengelompokan pada perkebunan tersebut dilakukan dengan menerapkan metode data mining teknik $K$-Means Clustering. Penggunaan metode tersebut akan menghasilkan kelompok data berdasarkan data-data yang mirip dan memiliki karakteristik yang sama.

\section{METODOLOGI}

Metode data mining dengan teknik $K$-Means Clustering digunakan pada penelitian segmentasi perkebuan kelapa sawit di Indonesia. Teknik ini digunakan untuk mendapatkan hasil pengelompokan atau segmentasi perkebunan kelapa sawit dari berbagai propinsi yang terdapat di Indonesia. Pendekatan yang diusulkan terdiri dari beberapa langkah untuk menghasilkan segmentasi yang terdiri dari: pengumpulan data, pengolahan data, dan analisis data.

\section{Proses Pengumpulan Data}

Data yang digunakan untuk melakukan pengelompokkan perkebunan kelapa sawit di Indonesia merupakan data sekunder, yaitu: data luas areal, data produksi, dan data produktivitas. Data tersebut merupakan jenis data kuantitatif yang didapatkan dari hasil publikasi 
Direktorat Jenderal Perkebunan, Kementerian Pertanian tahun 2021 melalui website https://ditjenbun.pertanian.go.id/. Data yang telah terkumpul berupa data luas areal, data produksi, dan data produktivitas pada perkebunan sawit yang terdapat di berbagai propinsi di Indonesia. Berdasarkan data tersebut diberikan variabel untuk setiap data yang digunakan, $\mathrm{X}_{1}=$ data luas areal, $\mathrm{X}_{2}=$ data produksi, dan $\mathrm{X}_{3}=$ data produktivitas. Pada data luas areal pertanian dilakukan penjumlahan antara tanaman yang menghasilkan (TM) dan tanaman rusak (TR). Tanaman rusak tetap diperhitungkan karena secara di lapangan tanaman tersebut masih menghasilkan walau tidak memadai lagi.

\section{Proses pengolahan data}

Data luas areal, data produksi, dan data produktivitas selanjutnya diolah menggunakan metode data mining dengan tahapan: pembersihan data; pengintegrasian data; penyeleksian data; transformasi data; data mining; dan representasi pengetahuan yang didapatkan dari hasil pengolahan data mining tersebut [17]. Gambar 1. merupakan proses untuk setiap tahapan dalam melakukan pengolahan data. Proses komputasi dilakukan dengan menggunakan software excel dan Rapid Miner untuk mempermudah proses pengolahan data.

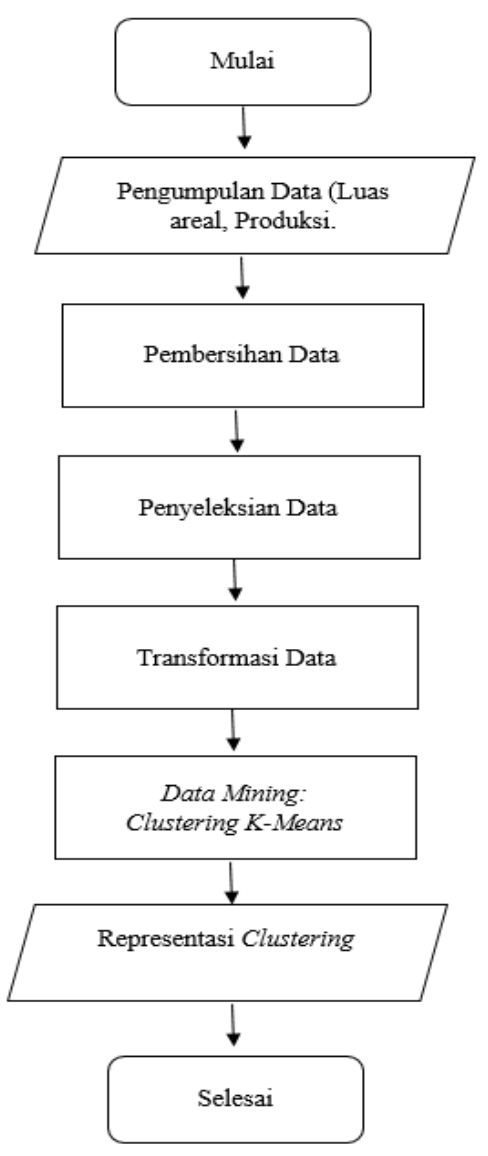

Gambar 2. Pengolahan Data Dengan Data Mining K-Means
Data mining dengan teknik K-Means Clustering akan dilakukan setelah data ditransformasikan. Pengelompokan data tersebut dilakukan dengan tahapan yang terdapat pada Gambar 2. Penentuan centroid dapat menggunakan rumus Euclidean sebagai berikut [18]:

$\sqrt{\sum_{i=1}^{n}(X i-Y j)^{2}}$

Keterangan:

$\mathrm{d}=$ jarak antara suatu titik dengan titik pusat,

$\mathrm{Xi}=$ nilai variabel ke $\mathrm{i}$ pada sampel $\mathrm{X}$,

$\mathrm{Yj}=$ nilai variabel ke $\mathrm{j}$ dari pusat clustering $\mathrm{Y}$.

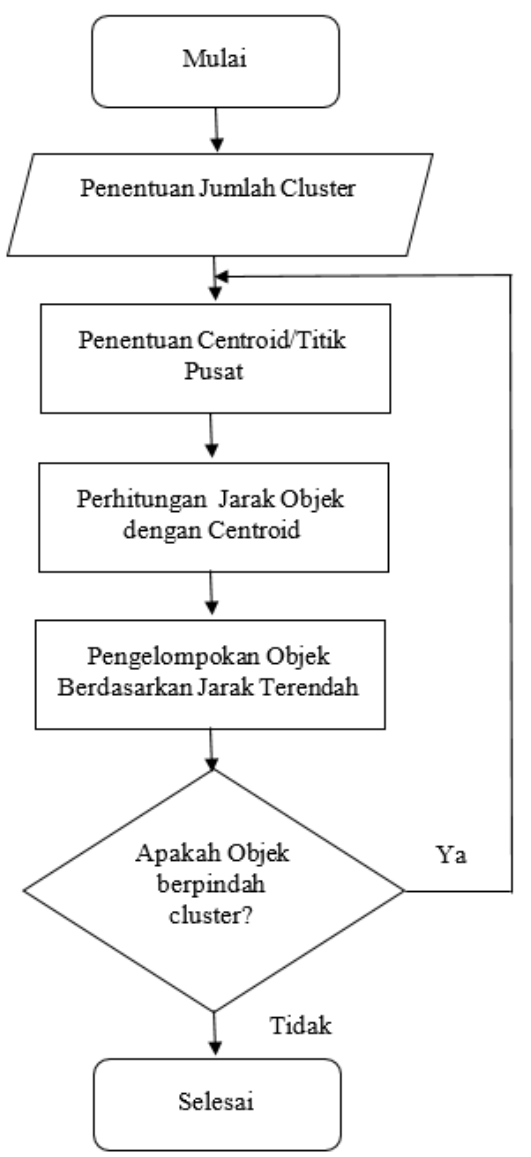

Gambar 3. Alur Proses Segmentasi dengan K-Means

Segmentasi dengan teknik $K$-Means Clustering pada data mining terdiri dari beberapa tahapan. Alur setiap tahapan pada teknik ini dapat dilakukan seperti pada Gambar 3. Hasil komputasi dari pengolahan data menggunakan teknik ini akan menghasilkan segmentasi perkebunan kelapa sawit pada wilayah Indonesia menjadi beberapa kelompok berdasarkan hasil kemiripan dari data luas areal, data produksi, dan data produktivitas.

\section{Analisis Data}

Tahap analisis merupakan tahap terakhir dalam proses segmentasi perkebunan tersebut. Setelah proses pengolahan data dengan teknik K-Means Clustering 
dilakukan, maka akan dilanjutkan dengan melakukan analisis lebih dalam guna mengetahui secara terperinci segmen perkebunan kelapa sawit yang terdapat diberbagai wilayah Indonesia berdasarkan karakteristik yang sama dari data luas areal, data produksi, dan data produktivitas.

Tabel 1. Data Luas Areal dan Produksi Kelapa Sawit Menurut Provinsi dan Keadaan Tanaman Tahun 2020

\begin{tabular}{|c|c|c|c|c|c|}
\hline Propinsi & $\begin{array}{c}\text { Luas Areal TBM } \\
\text { (Ha) }\end{array}$ & $\begin{array}{c}\text { Luas Areal TM } \\
\text { (Ha) }\end{array}$ & $\begin{array}{c}\text { Luas Areal TR } \\
\text { (Ha) }\end{array}$ & $\begin{array}{l}\text { Produksi } \\
\text { (Ton) }\end{array}$ & $\begin{array}{c}\text { Produktivitas } \\
\text { (Kg/Ha) }\end{array}$ \\
\hline Aceh & 97.261 & 360.302 & 30.440 & 1.134 .606 & 3.149 \\
\hline Sumut & 119.461 & 1.176 .501 & 29.117 & 5.776 .781 & 4.910 \\
\hline Sumbar & 41.451 & 337.604 & 14.254 & 1.312 .253 & 3.887 \\
\hline Riau & 330.605 & 2.441 .069 & 82.268 & 9.984 .315 & 4.090 \\
\hline Kepri & 2.079 & 5.140 & 178 & 20.020 & 3.895 \\
\hline Jambi & 192.179 & 840.481 & 41.939 & 3.022 .565 & 3.596 \\
\hline Sumsel & 141.012 & 1.022 .994 & 33.958 & 4.267 .023 & 4.171 \\
\hline Kep. Babel & 34.190 & 204.379 & 1.244 & 843.047 & 4.125 \\
\hline Bengkulu & 52.991 & 268.190 & 4.069 & 1.063 .404 & 3.965 \\
\hline Lampung & 18.601 & 172.710 & 5.001 & 384.948 & 2.229 \\
\hline D.K.I. Jakarta & - & - & - & - & - \\
\hline Jawa Barat & 599 & 12.865 & - & 33.093 & 2.572 \\
\hline Banten & 1.587 & 14.990 & 2.666 & 27.423 & 1.829 \\
\hline Jawa Tengah & - & - & - & - & - \\
\hline D.I. & - & & & & \\
\hline Yogyakarta & & - & - & - & - \\
\hline Jawa Timur & - & - & - & - & - \\
\hline Bali & - & - & - & - & - \\
\hline NTB & - & - & - & - & - \\
\hline NTT & - & - & - & - & - \\
\hline Kalbar & 316.531 & 1.666 .521 & 56.152 & 5.471 .407 & 3.283 \\
\hline Kalteng & 216.123 & 1.754 .028 & 48.509 & 7.685 .770 & 4.382 \\
\hline Kalsel & 67.055 & 410.288 & 19.917 & 1.561 .147 & 3.805 \\
\hline Kaltim & 205.300 & 1.088 .044 & 20.262 & 3.823 .221 & 3.514 \\
\hline Kaltara & 22.897 & 130.395 & 4.385 & 301.607 & 2.313 \\
\hline Sulawesi & - & & & & \\
\hline Utara & & - & - & - & - \\
\hline Gorontalo & 1.781 & 11.517 & - & 4.975 & 432 \\
\hline Sulteng & 26.255 & 113.890 & 5.727 & 371.717 & 3.264 \\
\hline Sulsel & 9.559 & 26.830 & 8.347 & 100.317 & 3.739 \\
\hline Sulbar & 38.225 & 100.732 & 17.223 & 348.015 & 3.455 \\
\hline Sultra & 11.030 & 93.695 & 5.576 & 76.300 & 814 \\
\hline Maluku & 794 & 9.799 & 259 & 19.145 & 1.954 \\
\hline Maluku Utara & 5.541 & - & - & - & - \\
\hline Papua & 28.674 & 111.855 & 19.191 & 557.559 & 4.985 \\
\hline Papua Barat & 5.126 & 45.892 & - & 106.413 & 2.319 \\
\hline
\end{tabular}

(Sumber: Ditjenbun, 2021)

\section{HASIL DAN PEMBAHASAN}

\section{Pengumpulan Data}

Data didapatkan dari publikasi Kementerian Pertanian yang terdiri dari data luas areal dan produksi kelapa sawit pada perkebunan rakyat (PR), besar negara (PBN) dan besar swasta (PBS) menurut propinsi serta keadaan tanaman pada tahun 2020 [3]. Dataset perkebunan kelapa sawit untuk setiap propinsi yang terdapat di wilayah
Indonesia yang berjumlah 34 data yang diperlihatkan pada Tabel 1. Data tersebut terdiri dari data propinsi, luas areal, produksi, dan produktivitas.

\section{Pembersihan Data}

Data yang terdapat pada Tabel 1. menuju ke langkah selanjutnya, yaitu melakukan pembersihan data. Pembersihan data sangat penting dilakukan agar data yang akan diolah menjadi lebih valid hasilnya. 
Pembersihan pada data mentah yang terdapat pada Tabel 1. diidentifikasi dan ditemukan terdapat data perkebunan kelapa sawit pada beberapa propinsi yang tidak memiliki nilai. Data yang tidak memiliki nilai tersebut, yaitu untuk Propinsi: D.K.I. Jakarta, Jawa Tengah, D.I. Yogyakarta, Jawa Timur, Bali, Nusa Tenggara Barat, Nusa Tenggara
Timur, Sulawesi Utara, dan Maluku Utara akan dihapus sebelum ke tahap penyeleksian data. Pembersihan data telah dilakukan dan menghasilkan data baru seperti yang terdapat pada Tabel 2. Data mengalami perubahan atau mengalami reduksi dimana pada awalnya data berjumlah 34 dataset menjadi 26 dataset.

Tabel 2. Tahapan Pembersihan Data

\begin{tabular}{|c|c|c|c|c|c|}
\hline Propinsi & $\begin{array}{l}\text { Luas Areal } \\
\text { TBM (Ha) }\end{array}$ & $\begin{array}{l}\text { Luas Areal TM } \\
\text { (Ha) }\end{array}$ & $\begin{array}{l}\text { Luas Areal TR } \\
\text { (Ha) }\end{array}$ & $\begin{array}{l}\text { Produksi } \\
\text { (Ton) }\end{array}$ & $\begin{array}{l}\text { Produktivitas } \\
\text { (Kg/Ha) }\end{array}$ \\
\hline Aceh & 97.261 & 360.302 & 30.440 & 1.134 .606 & 3.149 \\
\hline Sumut & 119.461 & 1.176 .501 & 29.117 & 5.776 .781 & 4.910 \\
\hline Sumbar & 41.451 & 337.604 & 14.254 & 1.312 .253 & 3.887 \\
\hline Riau & 330.605 & 2.441 .069 & 82.268 & 9.984 .315 & 4.090 \\
\hline Kepri & 2.079 & 5.140 & 178 & 20.020 & 3.895 \\
\hline Jambi & 192.179 & 840.481 & 41.939 & 3.022 .565 & 3.596 \\
\hline Sumsel & 141.012 & 1.022 .994 & 33.958 & 4.267 .023 & 4.171 \\
\hline Kep. Babel & 34.190 & 204.379 & 1.244 & 843.047 & 4.125 \\
\hline Bengkulu & 52.991 & 268.190 & 4.069 & 1.063 .404 & 3.965 \\
\hline Lampung & 18.601 & 172.710 & 5.001 & 384.948 & 2.229 \\
\hline Jawa Barat & 599 & 12.865 & - & 33.093 & 2.572 \\
\hline Banten & 1.587 & 14.990 & 2.666 & 27.423 & 1.829 \\
\hline Kalbar & 316.531 & 1.666 .521 & 56.152 & 5.471 .407 & 3.283 \\
\hline Kalteng & 216.123 & 1.754 .028 & 48.509 & 7.685 .770 & 4.382 \\
\hline Kalsel & 67.055 & 410.288 & 19.917 & 1.561 .147 & 3.805 \\
\hline Kaltim & 205.300 & 1.088 .044 & 20.262 & 3.823 .221 & 3.514 \\
\hline Kaltara & 22.897 & 130.395 & 4.385 & 301.607 & 2.313 \\
\hline Gorontalo & 1.781 & 11.517 & - & 4.975 & 432 \\
\hline Sulteng & 26.255 & 113.890 & 5.727 & 371.717 & 3.264 \\
\hline Sulsel & 9.559 & 26.830 & 8.347 & 100.317 & 3.739 \\
\hline Sulbar & 38.225 & 100.732 & 17.223 & 348.015 & 3.455 \\
\hline Sultra & 11.030 & 93.695 & 5.576 & 76.300 & 814 \\
\hline Maluku & 794 & 9.799 & 259 & 19.145 & 1.954 \\
\hline Maluku Utara & 5.541 & - & - & - & - \\
\hline Papua & 28.674 & 111.855 & 19.191 & 557.559 & 4.985 \\
\hline Papua Barat & 5.126 & 45.892 & - & 106.413 & 2.319 \\
\hline
\end{tabular}

\section{Penyeleksian Data}

Pembersihan data yang telah dilakukan akan diseleksi kembali, yaitu dilakukan pemilihan data yang tepat digunakan untuk proses segmentasi perkebunan kelapa sawit yang ditemukan di wilayah Indonesia. Hasil dari penyeleksian data yang terdapat pada Tabel 3 . didapatkan bahwa bahwa data luas areal tanaman menghasilkan (TM), luas areal tanaman rusak (TR), produksi, dan produkitvitas selanjutnya akan digunakan pada proses transformasi data. Pada data luas areal tanaman belum menghasilkan (TBM) tidak digunakan karena mengindikasikan bahwa pada areal tersebut kelapa sawit masih belum bereproduksi. Sedangkan, data tanaman rusak (TR) tetap dipakai mengingat tanaman tersebut terkadang masih menghasilkan kelapa sawit walaupun hasilnya tidak optimal.

Hasil seleksi menunjukkan bahwa Propinsi Maluku tereliminasi pada tahap ini. Hal ini disebabkan karena perkebunan kelapa sawit pada propinsi ini masih dalam bentuk tanaman belum menghasilkan, tidak ada tanaman yang menghasilkan maupun tanaman rusak. Indikasi dari hal tersebut menyatakan bahwa pada Propinsi Maluku perkebunan sawit belum bereproduksi atau tidak ada produktivitasnya, sehingga dilakukan penghapusan untuk propinsi ini. Dengan demikian data semula yang berjumlah 26 dataset berubah menjadi 25 dataset.

\section{Transformasi Data}

Data yang dihasilkan pada tahap penyeleksian data akan ditranformasi agar menghasilkan data yang tepat saat digunakan pada proses data mining $k$-means. Transformasi data dilakukan dengan melakukan seleksi atribut, dimana Pada Tabel 3. diketahui bahwa data luas areal pada tanaman menghasilkan (TM) dan luas areal pada tanaman rusak (TR) masih dalam bentuk data terpisah. Kedua data tersebut akan diintegrasikan menjadi satu data sehingga menghasilkan data baru yang selanjutnya disebut data luas areal total. Pada tahap transformasi data akan dihasilkan tiga variabel, yaitu: 
data luas areal total, data produksi, dan data produktivitas.

Hasil transformasi data dihasilkan sebanyak 25 dataset yang akan diproses menggunakan teknik $K$-Means Clustering. Sebelum melakukan eksekusi menggunakan teknik tersebut, setiap variabel diberikan atribut khusus untuk mempermudah proses pengolahannya. Pada Tabel
4. memperlihatkan nama propinsi diberikan atribut ID dengan memberi nomor id 1 sampai dengan 25. Lalu variabel lainnya seperti data luas areal total diberi atribut $\mathrm{X}_{1}$, data produksi diberi atribut $\mathrm{X}_{2}$ dan data produktivitas diberi atribut $X_{3}$. Data awal yang semula terdiri dari empat variabel mengalami perubahan bentuk menjadi tiga variabel.

Tabel 3. Penyeleksian Data

\begin{tabular}{lrrrr}
\hline Propinsi & Luas Areal TM (Ha) & Luas Areal TR (Ha) & Produksi (Ton) & Produktivitas (Kg/Ha) \\
\hline Aceh & 360.302 & 30.440 & 1.134 .606 & 3.149 \\
Sumut & 1.176 .501 & 29.117 & 5.776 .781 & 4.910 \\
Sumbar & 337.604 & 14.254 & 1.312 .253 & 3.887 \\
Riau & 2.441 .069 & 82.268 & 9.984 .315 & 4.090 \\
Kepri & 5.140 & 178 & 20.020 & 3.895 \\
Jambi & 840.481 & 41.939 & 3.022 .565 & 3.596 \\
Sumsel & 1.022 .994 & 33.958 & 4.267 .023 & 4.171 \\
Kep. Babel & 204.379 & 1.244 & 843.047 & 4.125 \\
Bengkulu & 268.190 & 4.069 & 1.063 .404 & 3.965 \\
Lampung & 172.710 & 5.001 & 384.948 & 2.229 \\
Jawa Barat & 12.865 & - & 33.093 & 2.572 \\
Banten & 14.990 & 2.666 & 27.423 & 1.829 \\
Kalbar & 1.666 .521 & 56.152 & 5.471 .407 & 3.283 \\
Kalteng & 1.754 .028 & 48.509 & 7.685 .770 & 4.382 \\
Kalsel & 410.288 & 19.917 & 1.561 .147 & 3.805 \\
Kaltim & 1.088 .044 & 20.262 & 3.823 .221 & 3.514 \\
Kaltara & 130.395 & 4.385 & 301.607 & 2.313 \\
Gorontalo & 11.517 & - & 4.975 & 432 \\
Sulteng & 113.890 & 5.727 & 371.717 & 3.264 \\
Sulsel & 26.830 & 8.347 & 100.317 & 3.739 \\
Sulbar & 100.732 & 17.223 & 348.015 & 3.455 \\
Sultra & 93.695 & 5.576 & 76.300 & 814 \\
Maluku & 9.799 & 259 & 19.145 & 1.954 \\
Papua & 111.855 & 19.191 & 557.559 & 4.985 \\
Papua Barat & 45.892 & - & 106.413 & 2.319 \\
\hline
\end{tabular}

\section{Clustering K-Means}

Data yang telah mengalami transformasi diolah lebih lanjut pada proses data mining guna melakukan segmentasi perkebunan kelapa sawit di wilayah Indonesia. Data mining digunakan pada segmentasi ini adalah teknik clustering k-means, yaitu membagi perkebunan kelapa sawit menjadi beberapa segmen berdasarkan dari tiga variabel luas areal $\left(\mathrm{X}_{1}\right)$, produksi $\left(\mathrm{X}_{2}\right)$, dan produktivitasnya $\left(\mathrm{X}_{3}\right)$. Segmentasi dilakukan dengan menggunakan software Rapid Miner. Hal pertama yang dilakukan adalah membuat proses desain $k$-means dengan cara melakukan impor data yang terdapat pada Tabel 4. dengan memilih algoritma $k$ means dan performance. Segmentasi ditentukan sebanyak 3 kelompok atau $\mathrm{K}=3$ yang memberikan informasi bahwa kelompok perkebunan terdiri dari kelompok perkebunan yang memiliki potensi hasil perkebunan kelapa sawit tinggi, kelompok perkebunan yang memiliki potensi hasil perkebunan kelapa sawit yang sedang, dan kelompok perkebunan yang memiliki potensi hasil perkebunan kelapa sawit yang rendah.

Tabel 4. Transformasi Data

\begin{tabular}{crrr}
\hline ID & \multicolumn{1}{c}{$\mathbf{X}_{\mathbf{1}}$} & \multicolumn{1}{c}{$\mathbf{X}_{\mathbf{2}}$} & $\mathbf{X}_{\mathbf{3}}$ \\
\hline 1 & 390.742 & 1.134 .606 & 3.149 \\
2 & 1.205 .618 & 5.776 .781 & 4.910 \\
3 & 351.858 & 1.312 .253 & 3.887 \\
4 & 2.523 .337 & 9.984 .315 & 4.090 \\
5 & 5.318 & 20.020 & 3.895 \\
6 & 882.420 & 3.022 .565 & 3.596 \\
7 & 1.056 .952 & 4.267 .023 & 4.171 \\
8 & 205.623 & 843.047 & 4.125 \\
9 & 272.259 & 1.063 .404 & 3.965 \\
10 & 177.711 & 384.948 & 2.229 \\
11 & 12.865 & 33.093 & 2.572 \\
12 & 17.656 & 27.423 & 1.829 \\
13 & 1.722 .673 & 5.471 .407 & 3.283 \\
14 & 1.802 .537 & 7.685 .770 & 4.382 \\
15 & 430.205 & 1.561 .147 & 3.805 \\
16 & 1.108 .306 & 3.823 .221 & 3.514 \\
17 & 134.780 & 301.607 & 2.313 \\
18 & 11.517 & 4.975 & 432 \\
\hline & & Yuniarti and Hayati 61
\end{tabular}




\begin{tabular}{rrrr}
\hline ID & \multicolumn{1}{c}{$\mathbf{X}_{\mathbf{1}}$} & \multicolumn{1}{c}{$\mathbf{X}_{\mathbf{2}}$} & $\mathbf{X}_{\mathbf{3}}$ \\
\hline 19 & 119.617 & 371.717 & 3.264 \\
20 & 35.177 & 100.317 & 3.739 \\
21 & 117.955 & 348.015 & 3.455 \\
22 & 99.271 & 76.300 & 814 \\
23 & 10.058 & 19.145 & 1.954 \\
24 & 131.046 & 557.559 & 4.985 \\
25 & 45.892 & 106.413 & 2.319 \\
\hline
\end{tabular}

Penentuan nilai centroid titik pusat didapatkan secara random dan otomatis dengan tipe pengukuran yang dipakai berupa numerical measures euclidian distance. Nilai centroid pada masing-masing segmentasi/cluster berdasarkan luas areal $\left(\mathrm{X}_{1}\right)$, produksi $\left(\mathrm{X}_{2}\right)$, dan produktivitas $\left(\mathrm{X}_{3}\right)$ yang digunakan sesuai dengan centroid table yang ditampilkan seperti pada Tabel 5.

Tabel 5. Data Centroid pada Centroid Table

\begin{tabular}{lrrr}
\hline Variabel & \multicolumn{1}{c}{ Cluster 0 } & \multicolumn{1}{c}{ Cluster 1 } & \multicolumn{1}{c}{ Cluster 2 } \\
\hline $\mathrm{X}_{1}$ & $142.753,7$ & $1.195 .193,8$ & 2.162 .937 \\
$\mathrm{X}_{2}$ & $459.221,6$ & $4.472 .199,4$ & $8.835 .042,5$ \\
$\mathrm{X}_{3}$ & $2.929,5$ & $3.894,8$ & $4.236,0$ \\
\hline
\end{tabular}

Tabel 6. merupakan hasil komputasi yang menampilkan nilai statistik maksimun, minimum, dan rata-rata untuk variabel $\mathrm{X}_{1}, \mathrm{X}_{2}$, dan $\mathrm{X}_{3}$.

Tabel 6. Statistik Nilai Maksimum, Minimum, dan Ratarata Setiap Variabel

\begin{tabular}{crrr}
\hline Variabel & Minimun & Maksimum & \multicolumn{1}{c}{ Rata-rata } \\
\hline $\mathrm{X}_{1}$ & 5.318 & 2.523 .337 & $514.855,72$ \\
$\mathrm{X}_{2}$ & 4.975 & 9.984 .315 & $1.931 .882,84$ \\
$\mathrm{X}_{3}$ & 432 & 4.985 & $3.227,08$ \\
\hline
\end{tabular}

Hasil proses k-means clustering didapatkan tiga model segmentasi seperti yang terdapat pada Tabel 7. Hasil segmentasi tersebut memberikan informasi bahwa segmen pertama atau cluster 0 terdiri dari 18 item, segmen kedua atau cluster 1 terdiri dari 2 item, dan segmen ketiga atau cluster 2 terdiri dari 2 item.

Tabel 7. Hasil Segmentasi Perkebunan Kelapa Sawit Tahun 2020 Menggunakan K-Means Clustering

\begin{tabular}{ll}
\hline Cluster & Jumlah \\
\hline Cluster 0 & 18 items \\
Cluster 1 & 5 items \\
Cluster 2 & 2 items \\
\hline
\end{tabular}

\section{Representasi Clustering K-Means}

Hasil komputasi memperlihatkan jumlah item setiap segmentasi perkebunan kelapa sawit yang terdapat pada propinsi di wilayah Indonesia. Representasi K-Means Clustering dapat dilihat berdasarkan Gambar 4. Pada gambar tersebut diketahui bahwa segmentasi 1 atau cluster 0 diperlihatkan dengan warna biru, yaitu merupakan kelompok perkebunan yang memiliki hasil perkebunan kelapa sawit yang rendah. Segmentasi 2 atau cluster 1 diperlihatkan dengan warna hijau, yaitu merupakan kelompok perkebunan yang memiliki hasil perkebunan kelapa sawit sedang. Segmentasi 3 atau cluster 2 diperlihatkan dengan warna oranye, merupakan kelompok perkebunan yang memiliki hasil perkebunan kelapa sawit yang tinggi.

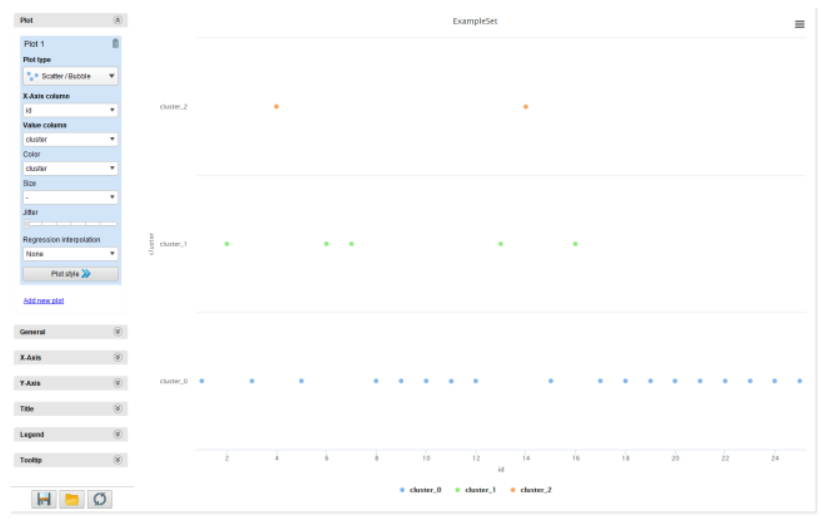

Gambar 4. Plot Hasil Segmentasi Perkebunan Kelapa Sawit di Indonesia

\section{Analisis Data}

Hasil pengolahan data menggunakan K-Means Clustering ditinjau dari tiga variabel luas areal $\left(\mathrm{X}_{1}\right)$, produksi $\left(\mathrm{X}_{2}\right)$, dan produktivitasnya $\left(\mathrm{X}_{3}\right)$ untuk perkebunan kelapa sawit yang terdapat di wilayah Indonesia menghasilkan tiga segmentasi/cluster. Segmentasi 1 atau cluster 0 merupakan kelompok perkebunan yang memiliki potensi hasil perkebunan kelapa sawit yang rendah, terdiri dari id: 1, 3, 5, 8, 9, 10, $11,12,15,17,18,19,20,21,22,23,24,25$. Pada segmen pertama dapat diketahui bahwa luas areal total terletak pada rentang 5.318 Ha sampai dengan 430.205 Ha, produksi pada rentang 4.975 Ton sampai dengan 1.561.147 Ton, dan produktivitas pada rentang 432 $\mathrm{Kg} / \mathrm{Ha}$ sampai dengan $4.985 \mathrm{Kg} / \mathrm{Ha}$.

Segmentasi 2 atau cluster 1 merupakan kelompok perkebunan yang memiliki potensi hasil perkebunan kelapa sawit sedang, terdiri dari id: 2, 6, 7, 13, 16. Pada segmen kedua dapat diketahui bahwa luas areal total terletak pada rentang $882.420 \mathrm{Ha}$ sampai dengan 1.722.673 Ha, produksi pada rentang 3.022.565 Ton sampai dengan 5.776.781 Ton, dan produktivitas pada rentang $3.283 \mathrm{Kg} / \mathrm{Ha}$ sampai dengan $4.910 \mathrm{Kg} / \mathrm{Ha}$.

Segmentasi 3 atau cluster 2 merupakan kelompok perkebunan yang memiliki potensi hasil perkebunan kelapa sawit yang tinggi, terdiri dari id: 4 dan 14. Pada segmen kedua dapat diketahui bahwa luas areal total terletak pada rentang 1.802.537 Ha sampai dengan 2.523.337 Ha, produksi pada rentang 7.685.770 Ton sampai dengan 9.984.315 Ton, dan produktivitas pada rentang $4.090 \mathrm{Kg} / \mathrm{Ha}$ sampai dengan $4.382 \mathrm{Kg} / \mathrm{Ha}$. 
Hasil performa diperlihatkan dari hasil Davies Bouldin Index (DBI) yang memiliki nilai sebesar 0,145. Hal ini menunjukkan kinerja pada centroid 3 segmentasi/cluster memberikan hasil yang terbaik karena nilai DBI mendekati nilai 0 . Perincian masing masing segmentasi/cluster dapat dilihat pada Tabel 8. yang memperlihatkan segmentasi untuk setiap propinsi. Segmentasi ini didapatkan dari kesamaan karakteristik perkebunan kelapa sawit suatu propinsi di wilayah Indonesia berdasarkan kemiripan dari data luas areal, data produksi, dan data produktivitas. Dari Tabel 8. Dapat diketahui bahwa dari $100 \%$ data didapatkan $72 \%$ provinsi yang memiliki karakteristik yang sama pada cluster 0 , sebanyak $20 \%$ provinsi yang memiliki karakteristik yang sama pada cluster 1 , dan $8 \% \%$ provinsi yang memiliki karakteristik yang sama pada pada cluster 2 .

Tabel 8. Hasil Segmentasi Perkebunan Kelapa Sawit di Wilayah Indonesia

\begin{tabular}{lccc}
\hline \multicolumn{1}{c}{ Propinsi } & Cluster 0 & Cluster 1 & Cluster 2 \\
\hline Aceh & $\sqrt{ }$ & $\sqrt{ }$ & \\
Sumut & & & \\
Sumbar & $\sqrt{ }$ & $\sqrt{ }$ \\
Riau & & & \\
Kepri & $\sqrt{ }$ & & \\
Jambi & & $\sqrt{ }$ \\
Sumsel & & & \\
Kep. Babel & $\sqrt{ }$ & \\
Bengkulu & $\sqrt{ }$ & \\
Lampung & $\sqrt{ }$ & \\
Jawa Barat & $\sqrt{ }$ & \\
Banten & $\sqrt{ }$ & \\
Kalbar & & $\sqrt{ }$ \\
Kalteng & & \\
Kalsel & $\sqrt{ }$ & \\
Kaltim & & $\sqrt{ }$ \\
Kaltara & $\sqrt{ }$ & \\
Gorontalo & $\sqrt{ }$ & \\
Sulteng & $\sqrt{ }$ & \\
Sulsel & $\sqrt{ }$ & \\
Sulbar & $\sqrt{ }$ & \\
Sultra & $\sqrt{ }$ & \\
Maluku & $\sqrt{ }$ & \\
Papua & $\sqrt{ }$ & \\
Papua Barat & $\sqrt{ }$ & \\
\hline
\end{tabular}

\section{KESIMPULAN}

Segmentasi perkebunan kelapa sawit di wilayah Indonesia dilakukan dengan menggunakan data mining teknik K-Means Clustering guna mengelompokkan perkebunan kelapa sawit berdasarkan data luas areal, produksi, dan produktivitas. Hasil dari tiga cluster yang ditentukan, diperoleh tiga segmentasi perkebunan kelapa sawit, yaitu 18 propinsi atau $72 \%$ termasuk dalam kelompok perkebunan yang memiliki potensi hasil perkebunan kelapa sawit rendah, 5 propinsi atau $20 \%$ termasuk dalam kelompok perkebunan yang memiliki potensi hasil perkebunan kelapa sawit sedang, dan 2 propinsi atau $8 \%$ termasuk dalam kelompok perkebunan yang memiliki potensi hasil perkebunan kelapa sawit kategori tinggi, yaitu Propinsi Riau dan Propinsi Kalimantan Tengah. Pada penelitian berikutnya dapat menambahkan variabel lainnya, seperti jumlah petani atau jumlah pekerja guna menghasilkan segmentasi yang lebih optimal pada perkebunan kelapa sawit yang terdapat di berbagai wilayah Indonesia.

\section{DAFTAR PUSTAKA}

[1] F. Verneau, F. La Barbera, M. Amato, and V. Sodano, 'Consumers' concern towards palm oil consumption an empirical study on attitudes and intention in italy," Br. Food J., vol. 121, no. 9, pp. 1982-1997, 2019.

[2] S. Hutabarat, "Optimalisasi Pemanfaatan Lahan Perkebunan Kelapa Sawit di Riau," Unri Conf. Ser. Agric. Food Secur., vol. 1, pp. 46-57, 2019.

[3] Direktorat Jenderal Perkebunan, "Statistik Perkebunan Unggulan Nasional 2019-2021," Angew. Chemie Int. Ed. 6(11), 951-952., 2021.

[4] R. Utami, E. I. Kumala Putri, and M. Ekayani, "Economy and Environmental Impact of Oil Palm Palm Plantation Expansion (Case Study: Panyabungan Village, Merlung Sub-District, West Tanjung Jabung Barat District, Jambi)," J. Ilmu Pertan. Indones., vol. 22, no. 2, pp. 115-126, 2017.

[5] M. H. Siregar, "Data Mining Klasterisasi Penjualan Alat-Alat Bangunan Menggunakan Metode K-Means (Studi Kasus Di Toko Adi Bangunan)," J. Teknol. Dan Open Source, vol. 1, no. 2, pp. 83-91, 2018.

[6] S. Handoko, F. Fauziah, and E. T. E. Handayani, "Implementasi Data Mining Untuk Menentukan Tingkat Penjualan Paket Data Telkomsel Menggunakan Metode K-Means Clustering," J. Ilm. Teknol. dan Rekayasa, vol. 25, no. 1, pp. 76-88, 2020.

[7] S. P. Tamba, F. T. Kesuma, and Feryanto, "Penerapan Data Mining Untuk Menentukan Penjualan Sparepart Toyota Dengan Metode K-Means Clustering," J. Sist. Inf. dan Ilmu Komput. Prima(JUSIKOM PRIMA), vol. 2, no. 
2, pp. 67-72, 2020.

[8] F. Indriyani and E. Irfiani, "Clustering Data Penjualan pada Toko Perlengkapan Outdoor Menggunakan Metode K-Means," JUITA J. Inform., vol. 7, no. 2, p. 109, 2019.

[9] C. Astria, A. P. Windarto, A. Wanto, and E. Irawan, "Metode K-Means pada Pengelompokan Wilayah Pendistribusian Listrik," Semin. Nas. Sains Teknol. Inf., pp. 306-312, 2019.

[10] U. B. Mulia, “Jumlah Ritel,” vol. XI, no. 1, pp. 32-44.

[11] M. Jesper, F. Pag, K. Vajen, and U. Jordan, "Annual Industrial and Commercial Heat Load Profiles: Modeling Based on k-Means Clustering and Regression Analysis," Energy Convers. Manag. X, vol. 10, no. March, p. 100085, 2021.

[12] I. M. Pulungan, M. Fauzan, and A. P. Windarto, "Implementasi Algoritma K-Means Clustering dalam Menentukan Blok Tanaman Sawit Paling Produktif," in Prosiding Seminar Nasional Riset Information Science (SENARIS), 2019, no. September, pp. 338348.

[13] R. A. D. Saragih, M. Safii, and H. S. Tambunan, "Penerapan Metode K-Means Clustering Untuk Mengelompokkan Kelapa Sawit Produktif," in Prosiding SiManTap: Seminar Nasional Matematika dan Terapan, 2019, pp. 362-370.

[14] D. F. Pasaribu, I. S. Damanik, E. Irawan, H. S. Tambunan, and K. Kunci, "Memanfaatkan Algoritma K-Means Dalam Memetakan Potensi Hasil Produksi Kelapa Sawit PTPN IV Marihat," BIOS J. Teknol. Inf. dan Rekayasa Komput., vol. 2, no. 1, pp. 11-20, 2021.

[15] P. Deepak and A. Jurek-loughrey, "MultiView Clustering," pp. 27-53.

[16] Y. Liu, X. Du, and S. Ma, Innovative study on clustering center and distance measurement of K-means algorithm: mapreduce efficient parallel algorithm based on user data of JD mall, no. 0123456789. Springer US, 2021.

[17] T. Yuniarti, I. Surjandari, E. Muslim, and E. Laoh, "Data Mining Approach for Short Term Load Forecasting by Combining Wavelet Transform and Group Method of Data Handling ( WGMDH )," in In 2017 3rd International Conference on Science in
Information Technology (ICSITech), 2017, pp. 53-58.

[18] B. Haihong, Z. Yiqun, S. Jianshuo, and Sh. Fangchu, "Study on power consumption load forecast based on K-means.pdf," in 2020 7th International Conference on Power and Energy Systems Engineering (CPESE 2020), 26-29 September 2020, Fukuoka, Japan, 2020, pp. 693-700. 